\title{
Trip Attraction Model on the Education Center on Pangilun Mountain Area, Padang City
}

\author{
Angelalia Roza ${ }^{1 *}$, Yessy Yusnita ${ }^{1}$, Andi Mulya Rusli ${ }^{2}$, Muchlisin $^{3}$ \\ ${ }^{1}$ Institut Teknologi Padang, Indonesia \\ ${ }^{I}$ Faculty of Engineering, Institut Teknologi Padang \\ ${ }^{2}$ Ministry of Public Works and Public Housing, Director General of Highways, Indonesia \\ ${ }^{3}$ Universitas Muhammadiyah Yogyakarta \\ *Corresponding author. angelaliaroza@gmail.com
}

\begin{abstract}
The purpose of this study was to model the travel attraction in the education area of Gunung Pangilun, Padang City. Primary data was collected by random sampling including 17 variables over 200 questionnaire responses. Crosstabs technique and multiple linear regression analysis were used to understand the trip attraction patterns in the study area. The result of the crosstabs analysis indicates a relationship between genders (X10), destination (X14), the mode of transportation used (X8), reasons for choosing the mode (X9), distance (X6), travel time (X7), and congestion (X17) to the total number of trips. Through multiple linear regression techniques, the amount of trip attractions (Y) is successfully explained through the Building Floor (X4), Trip Distance (X6), and Age (X11) variables. The model prediction is $\mathrm{Y}=-32,404+0,012 \mathrm{X} 4-3,899 \mathrm{X} 6+7,110 \mathrm{X} 11$.
\end{abstract}

Keywords_-Travel Attraction Modelling, Multiple Regression

\section{INTRODUCTION}

Padang city is the capital of West Sumatra Province located on the west coast of Sumatra Island. Padang city has an area of $694.96 \mathrm{~km}^{2}$, or $1.65 \%$ of the area of West Sumatra Province which consists of 11 sub-districts. The population growth of Padang City increases with the mobilization of people. Based on data from the Central Bureau of Statistics (BPS) Padang City in 2017 , the city has a population of 927,168 people [1]. The growth of political, economic, socio-cultural, and other sectors can be felt. The growth of these sectors leads transportation to have a very strategic role. Land use are categorized as educational areas, industrial areas, tourist areas, residential areas and trade/shopping areas, would create the specific impact to the transport behavior and attraction [2-4]. One of the factors affecting the level of community travel is the existence of central of education area located in Jalan Gajah Mada or precisely in the area of Gunung Pangilun, Padang City. There are various facilities are available, such as offices, shops, and schools. The advantages of this area are the availability of educational facilities, both informal such as solemn and formal places from kindergarten to higher education namely TK Raudhatul Athfal (RA) Ihklas, MTSN 6 Model Padang, MAN 2 Padang, STKIP PGRI West Sumatra.

The number of educational places in the area results in a crowded traffic flow, especially in the morning and evening. The number of land use functions that exist encourages the onset of attraction and rise, namely the number of movements to and leave the location that often cause traffic congestion especially during peak hours, the number of educational buildings in Gunung Pangilun area of Padang city certainly has a great influence on the attraction of travel. There has not been any study about how the model of travel attraction occurred in that area.

The increase in the number of private and public vehicles in Padang city often causes traffic jams on the roads. Especially in the education area on Jalan Gunung Pangilun, when increased movement causes public transportation or private vehicles to park or stop in the road body area, this affects the reduced capacity of the road which causes traffic congestion due to high traffic volume. Traffic congestion that occurs at the site can be prevented if the attraction can be calculated in the land use system. By knowing the number of attraction, it can be prepared and planned geometry and roads in the area.

From the existing conditions, it is necessary to model the travel attraction (trip attraction model) in the current condition. By considering the existence of many educational buildings in the area of Mount Pangilun in this model, the traffic problems in the future can be predict. The results of this study hopefully can be used as a reference for interested parties in formulating the policy of providing transportation facilities in the study area. More specifically, this research is expected to provide an overview of important variables that influence travel behavior in selecting modes of transport to Transmart, through a descriptive and mathematical approach $[5,6,8]$. 


\section{METHODOLOGY}

This research is reviewed namely Raudatul Athfal Kindergarten (RA) Ihklas, Madrasah Tsanawiyah Negri (MTSN) 6 Model Padang, Madrasah Aliyah Negri (MAN) 2 Padang, STKIP PGRI West Sumatra, located in Gunung Pangilun area, Padang City, West Sumatra. Data retrieval is done for 6 (six) days in 1 (one) week. The survey conducted in this study was conducted twice, where the first survey is a preliminary survey in Gunung Pangilun of Padang city conducted on November 11, 2019 by looking at the school buildings in Gunung Pangilun area, the second survey is an interview with respondents namely the filling of questionnaires and data collection by the school /campus is conducted on the working day of 16 - 21 December 2019.

Research instruments are compiled in paper-based questionnaires that test tried through preliminary surveys and have been validated [5]. Independent variables (X) used include:

Directly to the relevant school:

1. Number of Students $\left(\mathrm{X}_{1}\right)$

2. Number of Teachers /Lecturers $\left(\mathrm{X}_{2}\right)$

3. School/Campus Area $\left(\mathrm{X}_{3}\right)$

4. Building Floor Area $\left(\mathrm{X}_{4}\right)$

5. Number of Parking Spaces $\left(\mathrm{X}_{5}\right)$

Requested through questionnaire data:

6. Travel Distance to Campus/School $\left(\mathrm{X}_{6}\right)$

7. Travel time $\left(\mathrm{X}_{7}\right)$

8. Modes of transportation used $\left(\mathrm{X}_{8}\right)$

9. Reasons to Choose Mode $\left(\mathrm{X}_{9}\right)$

10. Gender $\left(\mathrm{X}_{10}\right)$

11. Age $\left(\mathrm{X}_{11}\right)$

12. Job $\left(\mathrm{X}_{12}\right)$

13. Number of Vehicles $\left(\mathrm{X}_{13}\right)$

14. Destination $\left(\mathrm{X}_{14}\right)$

15. Parking Capacity $\left(\mathrm{X}_{15}\right)$

16. Reasons to Choose A School/Campus ( $\left.\mathrm{X}_{16}\right)$

17. Congestion $\left(\mathrm{X}_{17}\right)$

Dependent Variable (Y) is the intensity of the attraction of the journey to school/campus. Ahern and Tapley (2008), in $[6,7]$, stated that the ideal number of respondents required perdesign was between 30 and 50 people. To test overall fit on linear regression models, the minimum sample size required is equal to $50+8 . \mathrm{K}$ ( $\mathrm{K}=$ number of variables) $[6,7]$. Thus, minimum number of sample sized (186 sample) should be considered.

\section{DISCUSSION}

Secondary data is obtained directly from the school/campus, then the data characteristics of the trip can be obtained from the spread of questionnaire spread directly to the respondent.

\subsection{Data Collection Results}

The primary data was collected from questionnaire results (200 respondents). The questionnaire contains characteristics of the trip. The secondary data was obtained through several information of the school/campus, which details as in Table I. Based on the data, the total number of students is 6237 people and the number of teachers/lecturers/employee 653 people. The total population is 6890 people. The questionnaires released are as many as 200 samples, or about $2.9 \%$ of the total population, the percentage breakdown of samples as shown in Table 2.

Table 1. Characteristics of Research Sites

\begin{tabular}{|c|c|c|c|c|}
\hline \multirow[b]{2}{*}{ Research Sites } & \multirow{2}{*}{$\begin{array}{l}\text { Land } \\
\text { Size } \\
\left(m^{2}\right)\end{array}$} & \multirow{2}{*}{$\begin{array}{c}\text { L. Floor } \\
\text { Building } \\
\quad\left(\mathrm{m}^{2}\right)\end{array}$} & \multicolumn{2}{|c|}{ Amount } \\
\hline & & & $\begin{array}{c}\text { Student } \\
/ \\
\text { Visitors }\end{array}$ & $\begin{array}{c}\text { Teacher/Lect } \\
\text { urer/Employ } \\
\text { ee }\end{array}$ \\
\hline $\begin{array}{l}\text { 1. TK Raudhatul } \\
\text { athfal (RA) Ikhlas }\end{array}$ & 522 & 257 & 217 & 15 \\
\hline $\begin{array}{l}\text { 2. MTSN } 6 \text { Model } \\
\text { Padang }\end{array}$ & 10000 & 7497 & 1261 & 135 \\
\hline 3. MAN 2 Padang & 19200 & 7715.93 & 1344 & 137 \\
\hline $\begin{array}{l}\text { 4. STKIP PGRI } \\
\text { Sumatra Barat }\end{array}$ & 7980 & 9632 & 3265 & 336 \\
\hline $\begin{array}{l}\text { 5. G-SPORTS } \\
\text { CENTER }\end{array}$ & 3059 & 2774 & 150 & 30 \\
\hline
\end{tabular}

Table 2. Percentage of survey sample spread

\begin{tabular}{|c|c|c|c|c|c|c|}
\hline \multirow{2}{*}{$\begin{array}{l}\text { Research } \\
\text { Sites }\end{array}$} & \multicolumn{3}{|c|}{ Student/Visitor } & \multicolumn{3}{|c|}{$\begin{array}{c}\text { Teacher/Lecturer/ } \\
\text { Employee }\end{array}$} \\
\hline & $\begin{array}{c}\text { Amou } \\
n t\end{array}$ & Sample & $\%$ & Amount & Sample & $\%$ \\
\hline $\begin{array}{l}\text { 1. TK } \\
\text { Raudhatul } \\
\text { athfal (RA) } \\
\text { Ikhlas }\end{array}$ & 217 & 0 & 0 & 15 & 14 & 15 \\
\hline $\begin{array}{l}\text { 2. MTSN } 6 \\
\text { Model } \\
\text { Padang }\end{array}$ & 1261 & 38 & 3 & 135 & 2 & 135 \\
\hline $\begin{array}{l}\text { 3. MAN } 2 \\
\text { Padang }\end{array}$ & 1344 & 41 & 3.1 & 137 & 2 & 137 \\
\hline $\begin{array}{l}\text { 4. STKIP } \\
\text { PGRI } \\
\text { Sumatra } \\
\text { Barat }\end{array}$ & 3265 & 91 & 2,8 & 336 & 10 & 336 \\
\hline $\begin{array}{l}\text { 5. G- } \\
\text { SPORTS } \\
\text { CENTER }\end{array}$ & 150 & 0 & 0 & 30 & 2 & 30 \\
\hline TOTAL & 6237 & 170 & 2.7 & 653 & 30 & 4.6 \\
\hline
\end{tabular}

\subsection{Travel Characteristics}

After conducted a field survey, data analysis can be obtained. It was tabulated according to the certain criteria of the group.

\subsection{Correlation Analysis}

Correlation testing is performed to measure the direction and strength of linear relationships between dependent and independent variables. The correlation analysis result used to consider the variable of the mode [4-8]. From the correlation test results of 17 attributes (school/campus characteristics and travel characteristics of respondents), it was shown that there were 3 attributes (Variable $\mathrm{X}$ ) that correlated with the 
intensity of the attraction of the trip to school/campus (Variable Y).

\subsection{Multiple Regression Analysis Techniques}

In determining the model of regression equation in use multiple regression analysis techniques [9]. Analysis involves SPSS tool taking into account method Enter and Stepwise. In the Stepwise method, the regression analysis is done gradually to the dominant predictor; where only influential variables are entered. As for the Enter Method, all free variables (variable $\mathrm{X}$ ) are entered as predictor variables regardless of whether or not they affect variable $Y$. The regression equation model are shown in Table 3.

Table 3. Percentage of survey sample spread

\begin{tabular}{|c|l|c|c|}
\hline No & \multicolumn{1}{|c|}{ Model Enter } & $\boldsymbol{R}^{2}$ & $\boldsymbol{F}$ \\
\hline 1. & $\begin{array}{l}\mathrm{Y}=-32.404+0.012 \mathrm{X}_{4}-3.899 \mathrm{X}_{6}+ \\
7.110 \mathrm{X}_{11}\end{array}$ & 0.695 & 148.60 \\
\hline No & \multicolumn{1}{|c|}{ Model Stepwise } & & \\
\hline 1. & $\mathrm{Y}=-18.360-0.011 \mathrm{X}_{4}$ & 0.643 & 356.14 \\
\hline 2. & $\mathrm{Y}=-43.350-0.012 \mathrm{X}_{4}+7.052 \mathrm{X}_{11}$ & 0.674 & 203.68 \\
\hline 3. & $\begin{array}{l}\mathrm{Y}=-32.404+0.012 \mathrm{X}_{4}-3.899 \mathrm{X}_{6}+ \\
7,110 \mathrm{X}_{11}\end{array}$ & 0.695 & 148.60 \\
\hline
\end{tabular}

Where $\mathrm{Y}$ is the attraction of the Journey to school/ campus, $\mathrm{X}_{4}$ is building floor Area, $\mathrm{X}_{6}$ is travel distance to campus/school, and $\mathrm{X}_{17}$ is Age.

From Table III, the results of the regression model using the Enter method are the same as those produced through the Stepwise method. Furthermore, there are 3 model shapes that will be considered further in determining the best model.

\subsection{Model Testing (Statistical Test)}

\subsubsection{Partial Significance Test ( Test $-t)$}

The basis of decision-making in the PaTest includes several criteria [5,7]. $\mathrm{H}_{0}$ is accepted if the value $\mathrm{t}_{\text {calculates }}<\mathrm{t}$ of

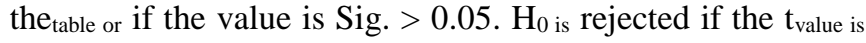
calculated $>t_{\text {table }}$ or if the value is Sig. $<0.05$. Where $t_{\text {table }}=$ $\mathrm{t}(\alpha / 2 ; \mathrm{n}-\mathrm{k}-1$ or $d f$ risidual $)$, with $\alpha=5 \%, \mathrm{n}=$ number of samples and $\mathrm{k}=$ number of variables $\mathrm{X}$.

\subsubsection{Test Analysis - F / Anova}

The basis of decision-making in the Test $-\mathrm{F}$ is as follows $[4,5,7,8]$. If the value of $F_{\text {counts }}>F_{\text {of the table and the value of }}$ significance $<0.05$, then the independent variable simultaneously affects the dependent variable. If the value of $\mathrm{F}_{\text {counts }}<\mathrm{F}_{\text {of the }}$ table and the significance value $>0.05$, then variable $\mathrm{Y}$ simultaneously has no effect on variable $\mathrm{X}$.
Table 4. Percentage of survey sample spread

\begin{tabular}{|c|c|c|c|c|c|}
\hline Model & $\begin{array}{c}\text { Independent } \\
\text { Variable }\end{array}$ & $\begin{array}{c}\text { t- } \\
\text { count }\end{array}$ & $\begin{array}{c}\mathrm{t}- \\
\text { table }\end{array}$ & Sig & Decision \\
\hline TP1 & $\mathrm{X}_{4}$ & 18.872 & 1.653 & 0.000 & Significant \\
\hline TP2 & $\mathrm{X}_{17}$ & $\begin{array}{c}19.760 \\
4.352\end{array}$ & $\begin{array}{l}1.653 \\
1.653\end{array}$ & 0.000 & $\begin{array}{l}\text { Significant } \\
\text { Significant }\end{array}$ \\
\hline TP3 & $\begin{array}{l}\mathrm{X}_{4} \\
\mathrm{X}_{6} \\
\mathrm{X}_{17}\end{array}$ & $\begin{array}{c}19.860 \\
-3634 \\
4.522\end{array}$ & $\begin{array}{l}1.653 \\
1.653 \\
1.653\end{array}$ & $\begin{array}{l}0.000 \\
0.000 \\
0.000\end{array}$ & $\begin{array}{l}\text { Significant } \\
\text { Significant } \\
\text { significant }\end{array}$ \\
\hline
\end{tabular}

Where $\mathrm{F}$ table $=\mathrm{F}(\mathrm{k} ; \mathrm{n}-\mathrm{k}$ or $d$ f residual $)$, with $\mathrm{n}=$ number of samples and $\mathrm{k}=$ number of variables $\mathrm{X}$. Recapitulation of Test Results $-\mathrm{F}$ can be seen in Table 5 .

Table 5. Percentage of survey sample spread

\begin{tabular}{|l|c|c|c|c|}
\hline \multicolumn{1}{|c|}{ Model } & F-count & t-table & Sig & Decision \\
\hline $\begin{array}{l}\mathrm{Y}=-18,360- \\
0,011 \mathrm{X}_{4}\end{array}$ & 356.145 & 2.65 & 0.000 & Significant \\
\hline $\begin{array}{l}\mathrm{Y}=-43,350- \\
0,012 \mathrm{X}_{4}+7,052 \\
\mathrm{X}_{11}\end{array}$ & 203.682 & 2.65 & 0.000 & Significant \\
\hline $\begin{array}{l}\mathrm{Y}=- \\
\begin{array}{l}32,404+0,012 \mathrm{X}_{4}- \\
3,899 \mathrm{X}_{6}+7,110\end{array}\end{array}$ & 148.602 & 2.65 & 0.000 & Significant \\
$\mathrm{X}_{11}$ & & & & \\
\hline
\end{tabular}

\subsubsection{Determination Test $\left(R^{2}\right)$}

The relationship between variable $\mathrm{Y}$ and variable $\mathrm{X}$ of each model can be seen from the value $R^{2}[8,9]$. Several models can be drawn, namely:

1. In the first model, the value of $R^{2}=0.643$ which means the travel time variable is only able to explain the travel attraction variable of $64.3 \%$.

2. In the second model, the value of $R^{2}=0.674$ which means the travel time variable is only able to explain the travel attraction variable of $67.4 \%$.

3 . In the third model, the value of $\mathrm{R}^{2}=0.695$ which means the travel time variable is only able to explain the travel attraction variable of $69.5 \%$.

\subsection{Multi collinearity Test}

This test is performed to know whether there is a strong correlation between variable $X[10,11]$. A good regression equation model should not occur correlation between variable $\mathrm{X}$. Detection of multi-collinearity can be known by looking at tolerance and its opponent Variance Inflation Factor (VIF). A variable is not exposed to multi-collinearity issues when the VALUE is VIF $<10$ and the tolerance value $>0.1$. Based on SPSS running program results, VIF value $<10$ and tolerance $>0.1$. This indicates that the symptoms of multi-collinearity in each model are not noticeable. 


\subsection{Auto Correlation Test}

To know the absence of auto correlation in regression, Durbin Watson $(D W)$ analysis was conducted $[5,8,9,12]$. Decision-making can be made as follows:

a. If the $D W$ test result value is below -2 , it is indicated positive auto correlation.

b. If the $D W$ test value is between -2 to 2 , it is indicated that there is no auto correlation.

c. If the $D W$ test value is above 2 , then it is indicated there is an auto negative correlation.

Based on Table 6 , the value of $D W=0.230$. Thus, it indicated a positive auto correlation.

Table 6. Auto correlation test

\begin{tabular}{|l|c|c|c|c|c|}
\hline \multicolumn{7}{|c|}{ Model Summary $^{\text {d }}$} \\
\hline Model & R & R Square & $\begin{array}{c}\text { Adjusted } \\
\text { R } \\
\text { Square }\end{array}$ & $\begin{array}{c}\text { Std. Error } \\
\text { of the } \\
\text { Estimate }\end{array}$ & $\begin{array}{c}\text { Durbin- } \\
\text { Watson }\end{array}$ \\
\hline 1 & $0.802^{\mathrm{a}}$ & 0.643 & 0.641 & Significant & \\
\hline 2 & $0.821^{\mathrm{b}}$ & 0.674 & 0.671 & Significant & \\
\hline 3 & $0.833^{\mathrm{c}}$ & 0.695 & 0.690 & Significant & 0.230 \\
\hline
\end{tabular}

${ }^{\text {a }}$ Predictors: (Constant), Building Floor Area ${ }^{b}$ Predictors: (Constant), Building Floor Area, Age c. Predictors: (Constant), Building Floor Area, Age, Travel Distance to Campus/School

${ }^{\mathrm{d}}$ Dependent Variable: Intensity of Travel Pull to campus/school

\subsection{Selection of the Best Regression Models}

The best models of regression is:

$$
Y=-32.404+0.012 X_{4}-3.899 X_{6}+7.110 X_{11}
$$

From the model, the negative signs indicate the closer the distance to campus/school the greater the intensity of the attraction to the campus/school. On the other hand, the positive signs on the model show the wider the floor of the school/campus building and the age of the respondent $<\mathrm{lt} ; 15$ years hence the greater the intensity of the attraction of the trip to the campus/school.

\section{CONCLUSION}

Model intensity of the best road in Gunung Pangilun area of Padang city produced are:

$$
Y=-32.404+0.012 X 4-3.899 X 6+7.110 X 11
$$

Where,

$\mathrm{Y}=$ Intensity of Travel attraction to campus/school

$\mathrm{X}_{4}=$ Building Floor Area

$\mathrm{X}_{6}=$ Travel distance to campus/school

$\mathrm{X}_{11}=$ Age
In this model the value of $\mathrm{R}^{2}=0.695$ which means the travel time variable has been able to explain the travel attraction variable of $69.5 \%$.

\section{REFERENCES}

[1] Badan Pusat Statistik of Padang City. Jumlah Penduduk Menurut Kecamatan dan Jenis Kelamin di Kota Padang, 2010$\begin{array}{lllll}2017 & \text { (Jiwa). } & 29 & \text { October } & 2018 .\end{array}$ https://padangkota.bps.go.id/statictable.html.

[2] Salmanur, M. Isya, \& R. Anggraini. "Attraction Model of Motorbike Movement in Shopping Center (Case Study of banda Aceh City) [Model Tarikan Pergerakan Sepeda Motor Pada Pusat Perbelanjaan (Studi Kasus: Di Kota Banda Aceh)]". Jurnal teknik sipil, 06 (03), 251-260, 2017.

[3] J. H. Frans. "Attraction Model of Transportation Movement in Lippo Plaza Area, Flobamora Mall and Hypermart BUndaran PU, Kupang City" [Model Tarikan Pergerakan Transportasi Pada Kompleks Lippo Plaza, Flobamora Mall dan Hypermart Bundaran PU Kota Kupang]. Jurnal Teknik Sipil, 05(02), 149$161,2016$.

[4] D. E. Intari. "Characteristics and Trip Generation in Shopping Center (Case Study of Mall of Serang in Serang City)" [Karakteristik dan Bangkitan Perjalanan Terhadap Pusat Perbelanjaan (Study Kasus Mall of Serang Di Kota Serang)]. Jurnal Fondasi, 04 (02), 59-68, 2015.

[5] O. Z. Tamin. (2000). Perencanaan dan Pemodelan Transportasi. Penerbit ITB, Bandung.

[6] R. Rita, A. M. Ismail, \& M. S. Asmirza. "Attraction Model in Traditional Market, Case Study of Padang Bulan market, Medan" [Model Tarikan Perjalanan Pada Pasar Tradisional Studi Kasus: Pasar Padang Bulan Medan]. Juranl Arsitektur “ATRIUM” Vol. 02 No.3, 34-41, 2005.

A. Roza. Intercity Land Public Transport Modal Choice Analysis by Stated Preference Methods: A Case Study in Kuala Lumpur - Penang Corridor, Jabatan Kejuruteraan Awam, Universiti Malaya. Malaysia, 2013.

[7] Roza, A. M. Rusli, \& M. R. Karim. "Challenge in Public Transport Specifically Land Transportation in Developed Country" [Tantangan Transportasi Umum Khususnya Moda Angkutan Darat Di Negara Berkembang: Studi Kasus Malaysia]. Jurnal Teknik Sipil ITP. Vol. 2, No. 1, 2015.

[8] Roza, Y. Yusnita, W. Mandasari. Permodelan Tarikan Perjalanan dengan Teknik Analisis Multiple Regression: Studi Kaus Kawasan Perbelanjaan Transmart, Kota Padang. Seminar Nasional SPI-4, 1-8. Padang, 10 Oktober 2019.

[9] Suriyadi, R. Anggraini, \& Azmeri. "Analysis of Trip Generation on Movement of Lampulo, Banda Aceh City" [Analisa Bangkitan Pergerakan Pada Kawasan Lampulo Kota Banda Aceh]. Jurnal Teknik Sipil, 01, 233-242, 2019.

[10] F. Widiarsih, A. S. Syafarudin, \& N. Kadarini. "Analysis of Trip Attraction Model of Vehicles in Resort Area (Study Case of Kubu Raya Regency)" [Analisis Model Tarikan Pergerakan Kendaraan Pada Tempat Wisata (Studi Kasus di Kabupaten Kubu Raya)]. Jurnal Mahasiswa Teknik Sipil Universitas Tanjungpura, 04 (04). Pontianak, 2017.

[11] Y. Yusnita, A. Roza, A. M. Rusli. "Modes Decision Model based on Vehicles Owner Variable and Category of Parking Area with Regression Analysis" [Model Pemilihan Moda Berdasarkan Variabel Kepemilikan Kendaraan dan Katagori Luas Lahan Parkir dengan Teknik Analisis Regresi]. Jurnal Pythagoras, Jurnal Program Studi Pendidikan Matematika. Vol. 9, No. 2, 2020. 